\title{
Analysis of Islamic Human Resources Performance Policy Management Practices in Private-Owned Enterprises in North Sumatera
}

\author{
Rodi Syafrizal \\ STIE Bina Karya, Tebing Tinggi, Sumatera Utara, Indonesia \\ rodisyafrizal@gmail.com \\ Fitrianingsih \\ STIE Bina Karya, Tebing Tinggi, Sumatera Utara, Indonesia \\ fitrianingsibbk@gmail.com \\ (C)2021 by the authors. Submitted for possible open access publication under the terms and conditions \\ of the Creative Commons Attribution (CC-BY-SA) license (https://creativecommons.org/licenses/by-sa/4.0/) \\ d. DOI : http://dx.doi.org/10.30983/es.v5i2.4813

\section{Abstract} \\ This study aims to analyze the practice of human resource management policies that are Muslim who work in privately \\ owned enterprises in the North Sumatra region. This research is a field research using a qualitative method. In the \\ practice of managing human resource performance policies, companies should be able to pay more attention to the \\ philosophy of understanding and religious values in their application so that they do not intersect with the beliefs and \\ needs of their HR worship. Islamic human resources considers that work is a form of worship that is carried out with \\ responsibility not only for the company but will be held accountable in the hereafter. Therefore, the policies or tasks \\ assigned by Muslim employees must be studied first so that they do not conflict with Islamic teachings or sharia. Muslims \\ do not only think that Islam is merely a religion that regulates the teachings of worship but also believes that it is a way \\ of life. Therefore, of course, every Muslim must be able to carry out his sharia in daily life and as an employee where \\ work is worship. Regardless of the spiritual and material needs that Muslim employees have obtained, it will certainly \\ have an impact on increasing employee performance. Therefore, it is important for every company to be able to adjust HR \\ management policies that are right on target so that they can encourage more effective performance which not only provides \\ material rights but also provides spiritual rights needed by $H R$.
}

Keywords: HR, Policy \& Performance

\section{Abstrak}

Penelitian ini dilakukan bertujuan untuk menganalisis praktik kebijakan pengelolaan sumber daya manusia yang beragama Islam yang bekerja pada Badan usaha milik swasta yang ada diwilayah Sumatera Utara. penelitian ini merupakan penelitian lapangan (field research) menggunakan metode kualitatif. Dalam praktik pengelolaan kebijakan kinerja sumber daya manusia seharusnya perusahaan harus mampu lebih memperhatikan filosofi pemahaman dan nilai-nilai keagamaan dalam penerapannya sehingga tidak bersinggungan dengan keyakinan dan kebutuhan ibadah SDM-nya. Islamic human resources menganggap bahwa kerja adalah sebagai ibadah yang dilaksanakan dengan tanggung jawab semata-mata bukan hanya pada perusahaan tetapi dipertanggung jawabkan diakhirat kelak. Oleh karena itu kebijakan atau tugas yang diberikan oleh karyawan muslim harus dipelajari terlebih dahulu sehingga tidak berbenturan dengan ajaran atau syariat Islam. Kaum muslim bukan hanya menganggap Islam semata-mata agama yang mengatur ajaran beribadah tetapi meyakini sebagai way of life. oleh karena itu tentu setiap muslim harus mampu melaksanakan syariatnya dalam kehidupan sehari-hari dan sebagai seorang karyawan dimana kerja sabagai ibadah. Dan apabila kebutuhan secara rohani dan materi ini telah diperoleh oleh karyawan muslim tentunya akan berdampak pada peningkatan kinerja karyawan. Oleh karena itu penting untuk setiap perusahaan harus mampu menyesuaikan kebijakan pengelolaan SDM yang tepat sasaran sehingga dapat mendorong kinerja lebih efektif dimana tidak hanya memberikan hak secara materi tetapi juga memberikan hak secara rohani yang dibutuhkan SDM.

Kata Kunci: SDM, Kebijakan, \& Kinerja 


\section{Background}

Religion is one thing that has a great influence on the development of society, especially in terms of culture and social values in it (Social values). The influence of the values that exist in society (Social Values) is the dominant beliefs and values of the wider community (eg individual freedom), collectivism, decency, cleanliness and so on. ${ }^{1}$ Indonesia is a country with the largest Muslim majority population in the world because 87 , $18 \%$ of Indonesia's population is a recorded number of 207, 176, 162 Indonesians are followers of Islam. Islam as one of the religions embraced by the majority of the Indonesian population, has given color to every aspect of the lives of its adherents. Starting from the aspect of workship, politics, social and Although Indonesia has the largest Muslim majority population in the world, the practice of Islamic studies has not been able to be applied perfectly because it is still dominated by conventional scientific studies.

Humans are the most important resource in an organization or company. But compared to graduating with it, humans are also the most complicated resource to understand in managing it. Performance problems are things that will never be separated from HR because performance is a real behavior that is displayed by everyone as work performance produced by HR in accordance with their role in the company. As Islamic Human Resources (HR) workers in an organization, they must carry out orders and obey regulations and carry out their duties properly which is something that is trustworthy and can be trusted as an employee. As IHR (Islamic Human Resources) you should be able to be part of

1 Teguh Suripto, 'Manajemen SDM Dalam Persfektif Ekonomi Islam", Jurnal Ekonomi Syariah Indonesia, Vol. 2, 2016', Jurnal Ekonomi Syariab Indonesia, Vol. 2 (2016). h. 240 the best members of the organization because as a Muslim upholds moral values and considers work as worship and an obligation that is not only accountable to the organization, it can still be accounted for in the hereafter. However, every HR has special needs which are not only material matters but also have spiritual or spiritual needs that must be fulfilled for the sake of comfort and trust in work.

Through the practice of Human Resources Management (HRM), it affects employees' perceptions of how much the company they work for pays attention to their welfare and believes that the resources they have given to the organization will be rewarded through policies in the field of HR. ${ }^{2}$

Sometimes companies are too focused on the obligations of workers and what workers have to give to the company instead of ignoring workers' rights. For companies, the most important thing is that workers receive compensation in the form of wages according to their working hours. The imbalance between the rights and obligations of HR is what triggers performance problems, such as less productive employees, ineffective employee performance. Most companies try to manipulate their organizations in accordance with the legal, political, and social values of the particular countries in which they operate, which results in the discrimination of human resources who seek to benefit the company by violating $\mathrm{HR}$ rights.

\section{a. Humans in Islamic Studies}

Humans as creatures who have special abilities and occupy the highest position among other creatures, namely being the caliph (representative) of God on earth. ${ }^{3}$

2 Tri Wikaningrum, 'Praktek Dan Kebijakan Manajemen Sumber Daya Manusia Pada Perbankan Syaria', Siasat Bisnis, Vol. 15 No. h. 100

3 Djaelany Haluty, 'Islam Dan Manajemen Sumber Daya ManusiaYang Berkualitas', Irfani, Volume. 10 (2014). h. 64 
The concept of caliph or in the sense of being called manager, in the concept of management there is a meaning of synergy which puts pressure on cooperation and mutual help in the sense that they work to achieve prosperity on this earth must be done without sacrificing other people (al-fasad), while if they gain advantages (al-fasad), -fadhl) should be used to benefit and help others. ${ }^{4}$ As the management of humans only as actors holding God's mandate, therefore humans in all the roles of their activities must follow the provisions (sharia) of Allah, not only mechanistic in nature and social life, but also theistic (rabbaniyyah) and moral and ethical (khuluqiyyah). Such perfection is intended so that humans become individuals who can develop themselves and become efficient members of society so that they can develop all the potential of their resources. ${ }^{5}$

There are things that humans will be responsible for, namely:

1) Man's duty as the caliph of Allah on earth

2) All the blessings of Allah that humans have ever received

3) All human behavior while living in this world

4) All pledges and promises made by humans. ${ }^{6}$

Humans have divine attributes such

as those of God. Such as power, will, knowledge, compassion, compassion, seeing, hearing, speaking and so on. But these qualities are not the same. God is the creator, while man is His creation. The Creator and His creation are not the same. Therefore, the attributes of God that exist in humans must be in accordance with their humanity. Therefore, Islam views humans as very noble with the source of its teachings, namely the Qur'an. He has photographed humans in their complete

4 Amiur Nurddin, 'SDM Berbasis Syariah', Tsaqafah, Vol.6, No. (2010). h.190

${ }^{5}$ Haluty. h. 65

${ }^{6}$ Haluty. h. 67 and comprehensive form. The divine attributes that exist in humans are actually a reflection of the commendable attributes of Allah.

\section{b. Basic Human Potential}

Humans are the most important element in the life of the world. There is no religion, ideology, school of philosophy, school of thought that denies the human aspect. It is not even an exaggeration to say that the world would not have been created without humans, both humans as actors of history, and as objects of their own historical journey.

In the Qur'an, the problem of human resources becomes a very important problem in the context of organizational, social and state life. Without quality human resources, whatever vision, mission, targets, goals, workplanning that has been prepared properly and ideally, will not be effective and functional. An organization, company, nation, religion, and even advanced civilization can certainly have quality, innovative and productive human resources.

Humans are the only beings who truly develop knowledge. He thought of new things, because he lived not just for survival, but more than that. Humans develop culture, humans give meaning to their lives, humans humanize themselves in their lives. ${ }^{8}$ Through a historical approach, Hasan Langgulung explained that in Ancient Greece the only human potential that had to be developed in the Spartan kingdom was his physical potential, but on the contrary in the Athens kingdom, the most important thing was the intelligence of his brain.?

${ }^{7}$ Haluty.

8 Asep Kurniawan, 'Pengembangan Sumber Daya Manusia Dalam Perspektif Epistemologi Filsafat Islam', Studi Keislaman Ulumuna, Volume 17 (2013). h. 312

${ }^{9}$ Haluty. h. 69 
Some Islamic philosophers have tried to classify potential in humans, including Muhaimin and Abdul Mujib who argue that essentially humans consist of two components, namely the body (physical) and the soul component (spiritual), according to them the physical component comes from the soil and the spiritual component. blown by God. From the opinion stated above, it turns out that human potential can be classified into physical potential and spiritual potential. In contrast to the classification stated above, some educational philosophers describe human spiritual potential into several parts, as Barmawie Umary argues that human spiritual potential consists of four main elements, namely spirit, qalb, nafs, and reason. The division of Barmawie Umary is slightly different from the classification of spiritual potential proposed by Muhaimin and Abdul Mujib. According to both of them, human spiritual potential is divided into three, namely, the potential for fitrah, qolb, and reason.

\section{c. Islamic Human Resources}

Human resources are productive individuals who work as members of the driving force of an organization, both in institutions and companies that have functions as organizational assets and the company itself. The definition of human resources (HR) can be divided into three meanings, namely (1) humans who work within an organization (personnel, labor, employees or employees), (2) Human Potential as a driving force for organizations to realize their existence, (3) Potential which is an asset and functions as capital (non-material) in a business organization that can be realized into real potential physically and non-physically in the existence of the organization. ${ }^{10}$

10 Harsuko Riniwati, Manajemen Sumberdaya Manusia (Malang: UB Press, 2016). h. 1
Islam is more of a "way of life" than a mere religion. In short, it teaches how a believer must oblige a commitment to his faith. Islam teaches compatibility and peaceful coexistence between human beings and instills a sense of understanding what is right and what is not. The values and ethics that are embedded in humans are reflected through their behavior. In the context of "Islam and Work," it highlights the obligation of the worker towards his work in particular between the company and its employees in general. The more committed to his religion, the more committed he (HR) to work. Therefore, according to Islamic teachings, work should be more dedicated to the agreed terms of work, the employee justifies his income and livelihood and at the same time Islamic human resources should be more prominent as role models for people who have different faiths (religions). The criteria for human resources in the view of Islam or the perspective of shari'ah are:

1) Believe and fear Allah SWT. The factor of faith and piety is the foundation of personality that can produce responsible workers.

2) Good character. A worker's faith will exude noble character, including responsibility, honesty and integrity, patience and perseverance, as well as commendable attitudes and traits that are applied to the work he does.

3) Physically healthy. Every Muslim worker needs to develop his physique through various efforts, including eating halal food, good nutrition, exercise, rest and balanced work.

4) Spiritual health. Includes mental stability in dealing with work assignments, having enthusiasm and passion for work that is always alive, enthusiastic and so on. 
5) Skilled. One of the absolute measures to determine qualified personnel is the skills in the field of tasks they face. ${ }^{11}$

Sherif in his research has identified nobility, patience, self-discipline, good looks, abstinence, determination, sincerity, truthfulness, servitude, and trust as the main values of Islam. This can obviously have an impact on management and employee productivity.

Islamic values related to the identification of the following job characteristics: ${ }^{12}$

a) Equality before God

b) Individual responsibility within the framework of cooperation with other parties

c) Respect and respect for employees must stand out

d) The principle of justice to be followed

e) Fatalism but also recognition of personal choice

f) Consultation at all levels of decision making.

The quality of human resources is very important, not only from the point of view of science and technology (IPTEK), however, it is equally important in the spiritual dimension, namely in the form of faith and piety (IMTAQ) in the quality of human resources. ${ }^{13}$

\section{d. Organization}

The organization is a group of people who are directed to achieve specific goals. The organization is basically used as a place or container where people gather, cooperate rationally and systematically, planned, organized, guided and controlled, in utilizing resources, such as human, financial facilities, data, and so on that are used

${ }^{11}$ Eni Haryani, 'Analisis Pengukuran Kinerja Universitas Islam Negeri Sumatera Utara Medan Berdasarkan Maslahah Scorecard' (Universitas Negeri Islam Sumtera utara, 2018). h. 42

12 Haryani. h. 42

13 Haluty. h. 70 efficiently and effectively to achieve a goal. ${ }^{14}$ Furthermore, Zonlu assumes that there are three main organizational resources, namely, human resources, financial resources, and technological resources. ${ }^{15}$

While Dubrin stated that as quoted by Wibisono, there are four forms of resources, namely: ${ }^{16}$

1. Human Resources are the workers needed to run. The achievement of organizational goals is influenced by workers who carry out the field of work.

2. Financial Resources are funds or money needed and used to finance work in order to achieve organizational goals.

3. Physical Resources are materials in the form of goods, in the form of facilities, tools, which are needed and used for the operation of the organization.

According to Lambooij, Sanders, Kosters and Zwiers in the results of their research, they conclude that there is a relationship between HR practices that are internally and strategically in accordance with cooperative employee behavior and organizational appearance. They classify organizational performance into two dimensions which are financial and nonfinancial performance.

Chand and Katoui argue that HR practices are positively related to the appearance of organizational performance. ${ }^{17}$ In organizing each individual can interact with all related structures either directly or

14 Kholid Musyaddad, 'Prinsip Prinsip Manajemen Sumber Daya Manusia Dalam Perspektif Islam', AL-Fikrab: Jurnal Kependidikan Islam IAIN Sulthan Thaha Saifuddin, Vol. 5 (2014). h. 7

15 Zorlu Senyucel, Manajing The Human Resources in the 21th Century (Zorlu Senyucel \& VentusPublishing ApS, 2009). h. 15

16 Wibisono, Manajemen Perubahan (Jakarta: RajaGrafindo, 2006). h. 11

17 Iihaamie abdul Azmi, 'Islmic Human Resources Practices and Organizations In Malaysia', Journal Of Global Business an Economics, Vol. 1 (2010). h. 30 
indirectly to the organization they choose. ${ }^{18}$ Active involvement in participating, does not only mean physical involvement.

Participation can be interpreted as mental involvement, thoughts, and emotions or feelings of a person in a group situation that encourages him to contribute to the group in an effort to achieve goals and take responsibility for the business concerned.

\section{e. Human Resource Management}

Human resource management (HRM) is one of the fields of general management which includes the following aspects: planning, organizing, implementing and controlling. This process is contained in the function of the work field contained in an organization.

Because human resources have an important role in achieving organizational goals, the experience and research results in the HR field are systematically collected hereinafter referred to as human resource management, which is the science, art and process of planning, organizing, coordinating, implementing, and monitoring activities. activities of procurement, development, provision of remuneration, integration, maintenance, and separation of workers so as to achieve organizational goals. ${ }^{19}$ The existence of human resources in an organization is a valuable asset for the organization itself. The success of an organization is determined by the empowerment and quality of its human resources and those within it. Human resource management is a form of "recognition" of the importance of the organization's workforce as a vital human resource for the attainment of organizational goals, and the utilization of various functions and personnel activities to ensure that they are used effectively for the

\footnotetext{
18 Winkel WS, Psikologi Pendidikan Dan Evaluasi Belajar (Jakarta: Gramedia, 1997). h. 75

${ }^{19}$ Musyaddad. h. 9
}

benefit of individuals, organizations. and society. ${ }^{20}$ Therefore, human resource management is needed to increase the effectiveness of human resources in the organization. The aim is to provide the organization with an effective work unit. ${ }^{21}$

\section{f. Islamic Human Resources Policy Management}

Human resource management in a company is vital and not easy for a company. Human resource management also means that the preparation and implementation of something must be coordinated to ensure that existing human resources can be utilized as well as possible to achieve the organization's goals. Human behavior is a combination of learning and experience.

How an individual human subject will behave and interact in a given situation will completely depend on the view of his soul that he wants to see a particular situation or event as. Reviewing the same basics from a business perspective, organizations manipulate themselves according to legal, political values. and social of the particular country in which they exist. These values and culture are what distinguish the character of organizations, communities, and individuals.

As a result, the operations and human resources (HR) of a business entity are handled as an environmental setting of the demands of that organization. Some research results conclude that in order to emphasize the

20 Rahayu Ningsih, Asyari Asyari, and Iiz Izmuddin, 'Pengaruh Islamic Human Capital Dan Pengembangan Karir Terhadap Kinerja Karyawan Bank Syariah', EKONOMIKA SYARLAH: Journal of Economic Studies, 4.2 (2020), 163-78; Hesi Eka Puteri, Anne Putri, and Sandra Dewi, 'Determinants of Extra-Role Behaviour of Lecturers in Islamic Higher Education', Jurnal Keilmuan Manajemen Pendidikan, 7.02 (2021), 12336

$<$ https://doi.org/10.32678/tarbawi.v7i02.4369.INTRO DUCTION>.

${ }^{21}$ T.Hani Handoko, Manajemen Personalia \& Sumberdaya Manusia (Yogyakarta: BPFE, 2008). h. 4 
universality and similarities between organizations, and some other uniqueness of organizations given a cultural context, according to Hofstede, one of the most influential values of society is cultural differences. Culture in each community group was identified as one of the main dimensions that accounted for the sharpest differences among employees. This can be called the individual difference factor. However, these differences within the organization do not trigger exclusive attitudes between employees, on the contrary they complement each other. In certain aspects of the organization it is permanently universal, such as the division of paths, hierarchical structure, division of functions, organizational processes, and information management; and some more culture-specific areas, such as human resource management (HRM). HRM is a significant aspect of an organization that is most likely to be affected by cultural influences. ${ }^{22}$

HRM policies are generally decided by the HRD division of the company, with or without consultation with its employees. But they do implement with some reference to the national context in which the organization operates. These include: national culture, political ideology of the government, economic conditions, trade unions, and the legal system. Similarly, religion in many countries, whether with secular or religious constitutions, has a degree of influence on the cultural characteristics of the people and their countries. This affects extreme and inclusive learning in countries that follow a model based on religious ideals, as shown in the following figure. $^{23}$

22 Ayesha Farooq dan Zareen Hussain Bilal Khan, 'Human Resource Management: An Islamic Perspective'. h. 18

${ }^{23}$ Bilal Khan. h. 19
Figure $1^{24}$

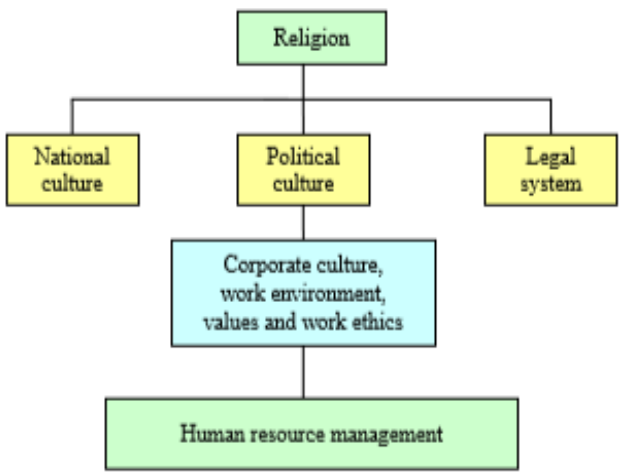

The spiritual and ethical reconstruction of the individual, society and world order is given within a socio-economic framework. Metwally in his research entitled "Economic consequences of applying Islamic principles in Muslim societies." (The economic consequences of applying Islamic principles in Muslim societies)" highlights the desire of many Muslim communities to be able to apply Islamic teachings in modeling their way of life, including their economic behavior.

Planning to achieve the company's ultimate goal must be done in such a way that it runs smoothly. IHR (Islamic Human Resources) as a Muslim must follow Islamic Shari'a (teachings) both in daily life as an Employee. ${ }^{25}$ For this reason, companies need to carry out policies to make adjustments to Islamic human resources as the Indonesian state is a country that bases the protection of human rights, including the right to freedom of religion and worship to God Almighty (YME) as the first principle of Pancasila which is the basis of philosophy. Country (Philosofish Grondslag). ${ }^{26}$

As explained in Article $28 \mathrm{E}$ paragraph (1) of the 1945 Constitution (UUD 1945), namely: "everyone is free to embrace religion and worship according to his religion, choose education and teaching, choose work, choose citizenship, choose a place to live in the territory of the country. and has the right

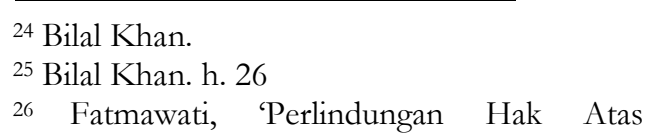
Kebebasan Beragama Dan Beribadah Dalam Negara Hukum Indonesia', Konsitusi, Volume 8, (2011). h. 493 
to leave and the right to return." ${ }^{27}$ In addition, Article 28 I paragraph (1) of the 1945 Constitution also recognizes that the right to religion is a human righ. ${ }^{28}$ Furthermore, Article 29 paragraph (2) of the 1945 Constitution also states that the State guarantees the independence of each of its residents to embrace religion. Article 28J paragraph (1) of the 1945 Constitution stipulates that everyone is obliged to respect the human rights of others. ${ }^{29}$

As further explained in Law Number 13 of 2003 concerning Manpower in Chapter III regarding equal employment opportunities and treatment, Article 5 which reads "Every worker has the same opportunity without discrimination to get a job" and in Article 6 which reads Every workers/ laborers are entitled to equal treatment without discrimination from employers. ${ }^{30}$

Job satisfaction is one of the dimensions of the welfare of company employees. The HRM practice itself also affects employees' perceptions of how much the company they work for cares about their well-being and believes that the resources they have given to the organization will be rewarded through policies in the field of HRM. Determination of fair compensation, continuous training programs, performance appraisals that have an impact on employee development, and the quality of communication with superiors, for example, perceive themselves to be treated well by the organization. Employees will feel obliged to treat the organization well \& try to avoid actions that are detrimental to the organization. In other words, employees feel

${ }^{27}$ Undang-Undang Dasar Republik Indonesia, Tentang Kebebasan Beragama Dan Beribadah, 1945, p. Pasal 28 E, Ayat 1 Tahun 1945.

28 Ayat 1 Tahun Undang-Undang Dasar Republik Indonesia Pasal 28 I, Tentang Hak Untuk Hidup, 1945.

${ }^{29}$ Undang-Undang Dasar Republik Indonesia, Tentang Menghormati Hak. Asasi Manusia., 1945, p. Pasal $28 \mathrm{~J}$, Ayat 1.

30 Undang-Undang Republik Indonesia, Tentang Ketenaga Kerjaan, 2003, p. Pasal 5 \& 6, Nomor 13 , Bab III. obliged to reciprocate to create a balance in exchange with the organization. ${ }^{31}$

\section{g. Performance of Islamic Human Resources}

Performance is everything that a person does and the results in carrying out the function of a job. Performance in Islam contains many Islamic norms and good ethics. Performance is the result of work that has been achieved by an individual, which is based on the criteria set by the organization both in quality and quantity achieved by an employee in a certain period of time and In carrying out his duties he does so with responsibility. In practice, performance is influenced by several factors. The factors that influence the work result/achievement of a person or group consist of internal and external factors. Internal factors that affect the performance of employees/groups consist of intelligence, skills, emotional stability, motivation, role perception, family conditions, one's physical condition and characteristics of the work group and so on. External influences include labor regulations, customer desires, competitors, social values, labor unions, economic conditions, changes in work locations and market conditions. ${ }^{32}$

In the Islamic perspective, the purpose of establishing an organization must be in line with the purpose of human life as the caliph of Allah on earth, there is an inseparable relationship between the nature and behavior of individuals in the organization as a whole. For this reason, organizations must provide benefits, both for individuals within the organization and for the wider community. Islamic teachings convey the message that work and religion itself are great sources of motivation for Muslims. A Muslim knows that when he is working, he is worshiping Allah and that is a powerful motivator in itself that sets him apart from any material gain. For a Muslim, wages and other material benefits are a means of buying food, clothing, housing, and providing for his family. He does not consider it a return of labor but he believes

\footnotetext{
31 Wikaningrum. h. 100

32 Haryani. h. 39
} 
that his work is worship and only Allah can reward him with paradise which will be the reward received by a Muslim worker who will do his work on the guidelines of the Quran. ${ }^{33}$

\section{Research Methods}

Qualitative methodology as a research procedure that produces descriptive data in the form of written or spoken words from people and observable behavior. This study uses a qualitative research approach that uses a natural setting, with the intention of interpreting phenomena that occur and is carried out by involving various existing methods and relying on observations to find facts with the right interpretation, accurately describing the characteristics of some group or individual phenomena. Descriptive approach aims to obtain an in-depth description of speech, writing, and observable behavior from an individual, group, community, or organization studied in a comprehensive perspective. $^{34}$

\section{Results and Discussion}

The results of the study indicate that the policies made by the company have a close and related relationship as if it is a reciprocal relationship between the company and employees where it seems as if employees reply to company policies given by the company through the performance they provide. From the results of interviews conducted that the company provides wages according to the previously agreed contract. The existence of giving rewards and careers that exist in the company is a policy that encourages a more productive work spirit.

Similarities between organizations, and several other unique organizations given a cultural context, according to Hofstede that one of the most influential societal values is cultural differences. Therefore, every company needs to study the culture that exists around the company which is a reflection of the

33 Bilal Khan. h. 27

34 Rosyadi Ruslan, Metode Penelitian Publlik Relation Dan Komunikasi (Jakarta: Raja Grafindo Persada, 2004). h. 213 human resources in the company both ethnically, culturally and religiously.

The company must be able to treat each employee fairly and not give an attitude of exclusivity to one particular entity or religion and give freedom in carrying out their worship to fulfill spiritual needs. This can be proven that the company has provided freedom in the implementation of worship and provided facilities in carrying out worship such as building a prayer room and carrying out religious socialization activities. Where this is in accordance with Bilal khal's theory which states that.

Culture in each community group was identified as one of the main dimensions that accounted for the sharpest differences among employees. This can be called the individual difference factor. However, these differences within the organization do not trigger exclusive attitudes between employees, on the contrary they complement each other. In certain aspects of the organization it is permanently universal, such as the division of paths, hierarchical structure, division of functions, organizational processes, and information management; and some more culture-specific areas, such as human resource management (HRM). HRM is a significant aspect of an organization that is most likely to be affected by cultural influences. ${ }^{35}$

The spiritual and ethical reconstruction of the individual, society and world order is given within a socio-economic framework. Metwally in his research entitled "Economic consequences of applying Islamic principles in Muslim societies." (The economic consequences of applying Islamic principles in Muslim societies)." highlights the desire of many Muslim communities to be able to apply Islamic teachings in modeling their way of life, including their economic behavior. ${ }^{36}$

Public companies managed by nonMuslim managers or leaders tend to often make mistakes between the duties and roles of Muslim employees in their field of work, for example, in welcoming other religious celebrations, the company provides costumes for welcoming consumers with knick-knacks

\footnotetext{
35 Bilal Khan. h. 18

36 Bilal Khan. h. 20
} 
for the celebration even though Islam does not tolerate this. For the need to understand the culture of the community so as to know the needs and rules that apply in the community.

Religion is one thing that has a great influence on the development of society, especially in terms of culture and social values in it (Social values). The influence of the values that exist in society (Social Values) is the dominant beliefs and values of the wider community (eg individual freedom, collectivism, decency, cleanliness and so on.

Islam as one of the religions embraced by the majority of the Indonesian population, has given color to every aspect of the life of its adherents. Starting from the aspect of worship, politics, social and economics. Islam as a religion is believed by Muslims not only as a teaching that regulates rituals of worship, but Muslims believe in Islam as a way of life. Al-Qur'an and hadith as the main sources and the two teachings of Islam contain instructions for humans in living their lives in the world. ${ }^{37}$ Planning to achieve the company's ultimate goal must be done in such a way that it runs smoothly. IHR (Islamic Human Resources) as a Muslim must follow Islamic Shari'a (teachings) both in daily life as an Employee. ${ }^{38}$

Job satisfaction is one of the dimensions of the welfare of company employees. The HRM practice itself also affects employees' perceptions of how much the company they work for cares about their well-being and believes that the resources they have given to the organization will be rewarded through policies in the field of HRM.

For this reason, companies need to carry out policies to make adjustments to Islamic human resources as the Indonesian state is a country that bases the protection of human rights, including the right to freedom of religion and worship to God Almighty (YME) as the first principle of Pancasila which

\footnotetext{
${ }^{37}$ Musyaddad. h. 2

38 Bilal Khan. h. 26
}

is the basis of philosophy. Country (Philosofish Grondslag). ${ }^{39}$

In the practice of managing human resource performance policies, companies should be able to pay more attention to the philosophy of understanding and religious values in their application so that they do not intersect with the beliefs and needs of their HR worship. Islamic human resources considers that work is a form of worship that is carried out with responsibility not only for the company but also for accountability in the hereafter. This shows that the values of Islamic faith must be contained in every Muslim human resource that worship is very important and must be carried out in balance with work or duties.

Where if these spiritual values run well without friction with work conditions and pressures, workers will feel more comfortable and sincere in carrying out their work without being burdened with a sense of compulsion or of course the performance of the HR will be better because it is not only material rights given but spiritually the company supports the implementation of worship and instills the values of worship in the work.

\section{Conclusion}

Every company must of course be able to identify the culture of the surrounding community group, learn about the existing culture which is a description of the existence needs of the community component, so by understanding its human resources, it must not only provide material rights, each company must also be able to provide spiritual rights in implementing and supporting worship activities.

Where to know ethics and limits in performance where to limit tasks that are less felt to intersect with the beliefs of the HR. By adjusting tasks to the implementation of worship and tolerating policies that are applied to religious rules that are believed to be. Islam is believed by Muslims to be not just a religion

\footnotetext{
${ }^{39}$ Fatmawati. h. 493
} 
that regulates the teachings of worship but believes it is a way of life. Therefore, of course, every Muslim must be able to carry out his sharia in daily life and as an employee where work is worship. Even if this spiritual and material need has been obtained by Muslim employees, it will certainly have an impact on increasing employee performance, this is in accordance with the results of a previous study by Tri Wika Ningrumm. He stated that job satisfaction is one of the dimensions that also affects employee perceptions of how Most of the companies where he works pay attention to their well-being and they will respond with the effectiveness of their performance

\section{Bibliography}

Books

Ahmadi, Ruslam. "Metodologi Penelitian Kualitatif”, cet. 3 ,Yogyakarta: Ar-Ruzz Media, 2016.

Amiruddin \& Asikin, Zainal.Pengantar Metode Penelitian Hukum Jakarta: Raja Grafindo Persada, 2008.

Arikunto, Suharsimi.Prosedur Penelitian, Suatu Pendekatan Praktek, Jakarta: Rineka Cipta, 2002.

Denzin, Norman K. \& Lincoln, Yvonna S. "Hand Book Of Qualitative Research", Terj. Dariyatno", Yogyakarta: Pustaka Pelajar, 2009.

Hani Handoko, T., "Manajemen Personalia \& Sumberdaya Manusia", BPFE: Yogyakarta, 2008.

Harsuko Riniwati, Manajemen Sumberdaya Manusia, UB Press : Malang, 2016.

J. Meleong.," Metodologi Penelitian Kualitatif, "Bandung: Rosda Karya, 2010.

Jogianto, H.M. "Metodologi PenelitianBisnis: Salah Kaprah dan PengalamanPengalaman", cet. 2, Yogyakarta: BPFE, 2009.

Kholil, Syukur. "Metodologi Penelitian", cet. Ke1, Bandung: CiptaPustaka Media, 2006.

Lexy, Moleong. "Metodologi Penelitian Kualitatif", Bandung: PT. Remaja Rosada Karya, 2001.
Muhamad, Danang. Metode Penelitian Ekonomi Islam Pendekatan Kualitatif, Jakarta: Rajawali Pers, 2008.

Nawawi, Hadari \& Martini, Mimi. "Penelitian Terpadu”, Yogyakarta: Gajah Mada University Press, 1996.

Ruslan, Rosyadi. Metode Penelitian Publlik Relation dan Komunikasi, Jakarta: Raja Grafindo Persada, 2004.

Sugiyono, "Memahami Penelitian Kualitatif", Bandung: Alfabeta, 2010

Sugiyono, .Metode Penelitian Kombinasi (Mixed Methods), Bandung: CV Alfabeta, 2013.

Sunyoto, Danang. Konsep Dasar Riset Pemasaran dan Perilaku Konsumen, Yogyakarta: CAPS, 2012.

Undang-Undang Dasar Republik Indonesia, Tahun 1945.

Undang-Undang Republik Indonesia Nomor 13 , Bab III , "Kesempatan Kerja Dan Perlakuan Yang Sama”,Tahun 2003 Tentang Ketenaga kerjaan.

Wibisono, Manajemen Perubaban, RajaGrafindo: Jakarta, 2006.

Winkel, WS. Psikologi Pendidikan dan Evaluasi Belajar, Gramedia; Jakarta, 1997

\section{Scientific Journals}

Abdul Azmi, Iihaamie. "Islmic Human Resources Practices and Organizations In Malaysia", dalam Journal of Global Business an Economics, Vol. 1, Juli 2010.

Afandi, Rifki. "Implementasi KuriKulum 2013 Dalam Mempersiapkan Sumber Daya Manusia Indonesia Menghadapi "Masyarakat Ekonomi ASEAN" (ASEAN Economic Community)" dalam Prosiding Seminar Nasional Pendidikan: Tema Implementasi Kurikulum,Vol. 1 November 2015.

Fatmawati, "Perlindungan Hak Atas Kebebasan Beragama Dan Beribadah Dalam Negara Hukum Indonesia" dalam Jurnal Konsitusi, Volume 8, Nomor 4 , Agustus 2011.

Haluty, Djaelany. "Islam Dan Manajemen Sumber Daya ManusiaYang Berkualitas" dalam Jurnal Irfani, Volume. 10 Nomor 1, Juni 2014. 
Haryani, Eni. "Analisis Pengukuran Kinerja Universitas Islam Negeri Sumatera Utara Medan Berdasarkan Maslahah Scorecard", Tesis, program Pascasarjan Universitas Negeri Islam Sumtera utara, 2018.

Khan, Bilal, et. al., "Human Resource Management: An Islamic Perspective" dalam Asia-Pacific Journal of Business Administration, Vol.Vol. 2, 2010.

Kurniawan, Asep. "Pengembangan Sumber Daya Manusia Dalam Perspektif Epistemologi Filsafat Islam"dalam Jurnal Studi keislaman Ulumuna, Vol. 17, No. 1, Juni 2013.

Musyaddad, Kholid. "Prinsip Prinsip Manajemen Sumber Daya Manusia Dalam Perspektif Islam", dalam $A L$ Fikrah: Jurnal Kependidikan Islam IAIN Sulthan Thaha Saifuddin, Vol. 5, 2014.

Ningsih, Rahayu, Asyari Asyari, and Iiz Izmuddin, 'Pengaruh Islamic Human Capital Dan Pengembangan Karir Terhadap Kinerja Karyawan Bank Syariah', EKONOMIKA SYARIAH: Journal of Economic Studies, 4.2 (2020), 163-78

Nuruddin, Amiur. "SDM Berbasis Syariah", dalam Jurnal Tsaqafah, Vol.6, No. 1, April 2010 .

Puteri, Hesi Eka, Anne Putri, and Sandra Dewi, 'Determinants of Extra-Role Behaviour of Lecturers in Islamic Higher Education', Jurnal Keilmuan Manajemen Pendidikan, 7.02 (2021), 123 36

$<$ https://doi.org/10.32678/tarbawi.v7i 02.4369

Suripto, Teguh. "Manajemen SDM Dalam Persfektif Ekonomi Islam", dalam Jurnal Ekonomi Syariah Indonesia, Vol. 2, No.2 Desember 2012.

Wikaningrum, T. "Praktek Dan Kebijakan Manajemen Sumber Daya Manusia Pada Perbankan Syariah", dalam Jurnal Siasat Bisnis, Vol.15, No. 1, Januari 2011. 